\title{
Influence of partially demineralized milk proteins on rheological properties and microstructure of acid gels
}

\author{
G. H. Meletharayil, ${ }^{* 1,2}$ H. A. Patel, ${ }^{*}$ L. E. Metzger, ${ }^{*}$ C. Marella, ${ }^{*}$ and T. Huppertz ${ }^{*} \dagger$ \\ *Midwest Dairy Foods Research Center, Department of Dairy Science, South Dakota State University, Brookings 57007-0647 \\ †NIZO BV, PO Box 20, 6710 BA Ede, the Netherlands
}

\begin{abstract}
Innovative clean label processes employed in the manufacture of acid gels are targeted to modify the structure of proteins that contribute to rheological properties. In the present study, $\mathrm{CO}_{2}$-treated milk protein concentrate powder with $80 \%$ protein in dry matter (TMPC80) was mixed with nonfat dry milk (NDM) in different ratios for the manufacture of acid gels. Dispersions of NDM and TMPC 80 that provided 100, 90, 70, and $40 \%$ of protein from NDM were reconstituted to $4.0 \%$ (wt/wt) protein and $12.0 \%$ (wt/wt) total solids. Dispersions were adjusted to $\mathrm{pH} 6.5$, followed by heat treatment at $90^{\circ} \mathrm{C}$ for $10 \mathrm{~min}$. Glucono- $\delta$-lactone was added and samples were incubated at $30^{\circ} \mathrm{C}$, reaching $\mathrm{pH} 4.5 \pm 0.05$ after $4 \mathrm{~h}$ of incubation. Glucono- $\delta$-lactone levels were adjusted to compensate for the lower buffering capacity of samples with higher proportions of TMPC80, which is attributable to the depletion of buffering minerals from both the serum and micellar phase during preparation of TMPC80. Sodium dodecyl sulfate-PAGE analysis indicated a higher amount of caseins in the supernatant of unheated suspensions with increasing proportions of $\mathrm{CO}_{2}$-treated TMPC80, attributable to the partial disruption of casein micelles in TMPC80. Heat treatment reduced the level of whey proteins in the supernatant due to the heat-induced association of whey proteins with casein micelles, the extent of which was larger in samples containing more micellar casein (i.e., samples with a lower proportion of TMPC80). Particle size analysis showed only small differences between nonheated and heated dispersions. Gelation $\mathrm{pH}$ increased from $\sim 5.1$ to $\sim 5.3$, and the storage modulus of the gels at $\mathrm{pH} 4.5$ increased from $\sim 300$ to $\sim 420 \mathrm{~Pa}$ when the proportion of protein contributed by TMPC80 increased from 0 to $60 \%$. Water-holding capacity also
\end{abstract}

\footnotetext{
Received August 10, 2017.

Accepted November 12, 2017.

${ }^{1}$ Current address: PepsiCo Global R\&D, 100 Stevens Avenue, Valhalla, NY 10595.

${ }^{2}$ Corresponding author: hari.meletharayil@pepsico.com
}

increased and gel porosity decreased with increasing proportion of protein contributed by TMPC 80 . The observed gel properties were in line with microstructural observations by confocal microscopy, wherein sample gels containing increasing levels of TMPC80 exhibited smaller, well-connected aggregates with uniform, homogeneous pore sizes. We concluded that TMPC80 can be used to partially replace NDM as a protein source to improve rheological and water-holding properties in acid gels. The resultant gels also exhibited decreased buffering, which can improve the productive capacity of yogurt manufacturing plants. Overall, the process can be leveraged to reduce the amount of hydrocolloids added to improve yogurt consistency and water-holding capacity, thus providing a path to meet consumer expectations of clean label products.

Key words: milk protein concentrate, carbon dioxide, acid gel, yogurt

\section{INTRODUCTION}

Yogurt is a popular product in the United States, with per capita consumption increasing significantly over the years (Fisberg and Machado, 2015). Manufacture of yogurt and other acidified dairy products involves several processing steps that may influence the rheological properties and microstructure of the resultant products. Acid gels from heated milk samples are reported to have an increased elastic modulus when compared with unheated milk samples, which is reported to be the result of an increase in heat-induced interactions between caseins and whey proteins (Lucey and Singh, 1997). Whether casein-whey protein interactions occur on the casein micelle surface or in the serum phase, they can have profound effects on the rheological properties of acid gels. Differences in $\mathrm{pH}$ at heat treatment can alter the distribution of denatured whey proteins. With increasing $\mathrm{pH}$ at heat treatment, the amount of denatured whey protein, as well as $\kappa$-CN, in the serum phase increases whereas that in the micellar phase decreases (Vasbinder and deKruif, 2003). These changes in protein distribution as a result of heating at 
different $\mathrm{pH}$ levels also affect the properties of acid gels, with higher elastic moduli and firmness observed for acid gels prepared from milk samples heated at higher pH (Anema et al., 2004). Thus, preheating of milk and adjusting preheating $\mathrm{pH}$ are very common strategies applied by processors to improve the rheological properties of acid gels.

Improvement of product rheological and textural properties beyond what can be achieved by heating and adjustment of preheating $\mathrm{pH}$ are obtained by addition of hydrocolloids. However, the use of hydrocolloids as food additives is increasingly being perceived as a negative by consumers (Aoki et al., 2010); therefore, demand exists for other strategies to improve the rheological and textural properties of acid gels. Use of additives such as transglutaminase (Faergemand and Qvist, 1997), chymosin (Gastaldi et al., 2003), and trisodium citrate (Ozcan-Yilsay et al., 2007) have been applied to improve the rheological properties of acid gels. Changing the ratio and levels of micellar and globular proteins (Lucey and Singh, 1997; Puvanenthiran et al., 2002), high-pressure processing (Huppertz et al., 2004; Anema et al., 2005), and altering the ionic strength and $\mathrm{Ca}^{2+}$ ion activities of milk or dispersions for the manufacture of acid gels (Meletharayil et al., 2015) are some of the other strategies available for improving the gel strength of acidified products.

An alternate strategy for improving acid gel properties via shifts in protein and mineral distributions is the use of modified milk protein ingredients. More recently, Marella et al. (2015) reported on the manufacture of a demineralized milk protein concentrate (MPC) obtained by application of $\mathrm{CO}_{2}$ during the UF and diafiltration (DF) stages of MPC with $80 \%$ protein in dry matter production. In addition to the previously reported improvement in solubility of this $\mathrm{CO}_{2}$-treated $\mathrm{MPC}$ with $80 \%$ protein in dry matter (TMPC80; Marella et al., 2015), we hypothesized that the increased levels of nonmicellar caseins in this product due to the removal of colloidal calcium phosphate (CCP) could aid in the improvement of acid gel properties. Considering this, the objective of the present study was to evaluate the acid gelation of dispersions containing different ratios of total protein derived from nonfat dry milk (NDM) and TMPC80.

\section{MATERIALS AND METHODS}

\section{Materials and Manufacture of $\mathrm{CO}_{2}$-Treated MPC Powders}

Nonfat dry milk [low heat, with greater than $6 \mathrm{mg} / \mathrm{g}$ (wt/wt) of undenatured whey protein nitrogen] was obtained from Associated Milk Producers (AMPI Inc.,
New Ulm, MN). All chemicals and reagents were purchased from Fisher Scientific (Pittsburgh, PA) unless otherwise indicated.

The TMPC80 was prepared at South Dakota State University as described by Marella et al. (2015). Briefly, $\mathrm{CO}_{2}$ was injected prior and during UF of pasteurized $\left(72^{\circ} \mathrm{C}\right.$ for $\left.15 \mathrm{~s}\right)$, skimmed bovine milk at $\sim 10^{\circ} \mathrm{C}$ using $10-\mathrm{kDa}$ spiral-wound polyethersulfone membranes, followed by spray-drying of the retentate using a Niro pilot scale dryer (ASO412E, Niro Inc., Columbia, MD). Total solids $(95.92 \%)$, fat $(2.51 \%)$, protein $(77.51 \%)$, ash $(4.96 \%)$, lactose $(10.53 \%)$, and calcium $(1.32 \%$; all $\mathrm{wt} / \mathrm{wt}$ ), in the powders was determined as outlined by Marella et al. (2015).

\section{Preparation of Milk Protein Dispersions for the Manufacture of Acid Gels}

Milk protein dispersions were prepared by reconstituting NDM, TMPC80 powder, and lactose powder in demineralized water to achieve $4.0 \%$ (wt/wt) protein and $12.0 \%$ (wt/wt) TS, with the amount of NDM added to provide $100,90,70$, and $40 \%$ (wt/wt) of total protein in the dispersion and the remainder from TMPC80. Dry ingredients were added to the calculated amount of demineralized water, stirred for $20 \mathrm{~min}$, and left overnight at $4^{\circ} \mathrm{C}$ for hydration. Dispersions were preserved with $0.02 \%$ (wt/wt) of sodium azide. After overnight storage, $\mathrm{pH}$ of dispersions was adjusted to 6.5 at $30^{\circ} \mathrm{C}$ with $1 \mathrm{~N} \mathrm{HCl}$ or $1 \mathrm{~N} \mathrm{NaOH}$ under stirring. Samples were allowed to equilibrate for $2 \mathrm{~h}$, followed by a readjustment of $\mathrm{pH}$, if required. The dispersions were then heated at $90^{\circ} \mathrm{C}$ for $10 \mathrm{~min}$ in a water bath followed by rapid cooling to $\sim 4^{\circ} \mathrm{C}$ in an ice bath. Unheated sample dispersions were also stored at $4^{\circ} \mathrm{C}$.

\section{Properties of Milk Protein Suspensions}

The method of Meletharayil et al. (2015) was used to determine the protein distribution in heated and unheated milk protein suspensions. The supernatants (centrifuged at $25,000 \times g$ for $1 \mathrm{~h}$ at $20^{\circ} \mathrm{C}$ ) of samples were analyzed by SDS-PAGE under reducing conditions. Stained gels were scanned on a Microtek gel scanner, Bio-500 (Microtek International Inc., Hsinchu, Taiwan).

The Z-average mean diameter measurements in heated and unheated milk protein suspensions were determined by dynamic light scattering, as outlined by Meletharayil et al. (2015), using a Malvern Zetasizer Nano-ZS (Malvern Instruments Ltd., Malvern, UK). Buffering of heated milk protein dispersions (30 g) was determined by monitoring $\mathrm{pH}$ as a function of added 
$0.5 \mathrm{~N} \mathrm{HCl}$ at $30^{\circ} \mathrm{C}$ from $\mathrm{pH} 6.5$ to 3.0 , as outlined by Meletharayil et al. (2015).

\section{Acid Gelation of Milk Protein Suspensions}

Acid gels were prepared at $30^{\circ} \mathrm{C}$ by addition of predetermined amounts of glucono- $\delta$-lactone (GDL) $(\sim 2$ $\mathrm{g} / 100 \mathrm{~g}$ of suspension) so that a final $\mathrm{pH}$ of $4.5 \pm 0.05$ was achieved for all samples after a 4-h incubation. A Stresstech HR rheometer (ATS Rheosystems, Rheological instruments Inc., Bordentown, NJ) was used to monitor acid gel formation from heated milk protein suspensions, as outlined by Meletharayil et al. (2015). Of the $30 \mathrm{~mL}$ of a dispersion containing GDL (mixed for 5 min after addition of GDL) that was prepared, $14 \mathrm{~mL}$ was transferred into the cup of a cup and bob measuring geometry (CC $25 \mathrm{CCE}$ ). Vegetable oil that served as a moisture trap was added to the surface of the dispersions during rheological experiments. Dispersions were then subjected to a strain-controlled oscillatory measurement profile (1\% strain and an angular velocity of $0.63 \mathrm{rad} / \mathrm{s})$ at $30^{\circ} \mathrm{C}$. The elastic modulus $\left(\mathbf{G}^{\prime}\right)$ was measured every $5 \mathrm{~min}$ for $240 \mathrm{~min}$. The $\mathrm{pH}$ measurement (Eutech Instruments, Cyber scan pH110, Thermo Scientific, Waltham, MA) during the gelation process was followed in a portion of the dispersion maintained at $30^{\circ} \mathrm{C}$ in a water bath and data were continuously logged by a computer; $\mathrm{pH}$ at the end of the gelation process was $4.5 \pm 0.05$.

\section{Properties of Acid Gels}

For determination of the water-holding capacity (WHC) of acid gels, $20 \mathrm{~g}$ of a sample containing the predetermined quantity of added GDL was placed in a 50-mL centrifuge tube. Following a 4 -h incubation at $30^{\circ} \mathrm{C}$ to attain $\mathrm{pH} 4.5$, the tube was transferred to a refrigerator and stored overnight, followed by centrifugation step at $3,000 \times g$ for $15 \mathrm{~min}$ at $4^{\circ} \mathrm{C}$, as outlined by Imm et al. (2000). Water-holding capacity was expressed as the ratio of the weight of pellet to the total weight of milk and expressed as a percentage.

Microstructure and resulting porosity of acid gels were studied by performing image analysis on confocal laser scanning microscopy images captured, as outlined by Meletharayil et al.(2015). Acridine orange was added at $140 \mu \mathrm{L}$ of $0.02 \%$ (wt/vol) to $20 \mathrm{~g}$ of heated dispersions, tempered to $30^{\circ} \mathrm{C}$, to stain proteins. After addition of the calculated quantity of GDL and mixing for $5 \mathrm{~min}, 240 \mu \mathrm{L}$ of this mixture was placed in a cavity of a depression slide. After incubation for $4 \mathrm{~h}$ at $30^{\circ} \mathrm{C}$ for the formation of acid gels, slides were transferred to a refrigerator for $12 \mathrm{~h}$ before imaging. Confocal mi- croscopy was performed using an Olympus Fluoview 1200 confocal (Olympus Corp., Tokyo, Japan) scanning laser microscope with an air-cooled $\mathrm{Ar} / \mathrm{Kr}$ laser. The excitation wavelength used was $488 \mathrm{~nm}$ with a $60 \times$ oil immersion lens. Captured images were converted to 8-bit grayscale images for analysis. ImageJ software (US National Institutes of Health, Bethesda, MD) was used to perform the grayscale image analysis. The porosity of the gels was expressed as an area fraction percentage that was defined as the ratio of pixels contributed by the pores in an image to the total number of pixels in that image.

\section{Statistical Analysis}

Experimental data were tested by ANOVA and significance was indicated by $P<0.05$, using SAS statistical software (version 9.3, SAS Institute Inc., Cary, $\mathrm{NC}$ ). Acid gels were manufactured 3 times and each experiment was repeated at least twice.

\section{RESULTS AND DISCUSSION}

\section{Properties of Milk Protein Suspensions}

Reducing SDS-PAGE electrophoretograms of unheated milk protein suspensions showed that the level of caseins in supernatants increased with increasing proportions of TMPC80 in the samples (Figure 1, gel A). The fact that levels of all individual caseins increased in equal proportion suggests that the increases in nonsedimentable caseins were related to disruption of casein micelles during the preparation of TMPC80. Micellar disruption is probably the result of solubilization of CCP due to the decrease in $\mathrm{pH}$ caused by $\mathrm{CO}_{2}$ injection and followed by removal of solubilized CCP during UF and DF (Marella et al., 2015). In the manufacture of TMPC80, acidification of milk by $\mathrm{CO}_{2}$ reduced the $\mathrm{pH}$ of milk to around 5.9, thus achieving a partial solubilization of calcium phosphate. The process of UF or DF coupled with $\mathrm{CO}_{2}$ treatment ensured that soluble calcium, phosphates, and citrates could pass into the permeate to yield a retentate with lower ash and calcium levels when compared with control (Table 1). Marella et al. (2015) reported a 28\% reduction in mineral content and a $33 \%$ decrease in calcium levels of TMPC powders when compared with control. Gevaudan et al. (1996) reported no difference in soluble phase proteins of milk subjected to $\mathrm{CO}_{2}$ treatment followed by depressurization when compared with the non- $\mathrm{CO}_{2}-$ treated control. This observed phenomenon could be a result of reaggregation of casein micelles upon depressurization of milk subjected to $\mathrm{CO}_{2}$ treatment when no 
Table 1. Calculated composition of dispersions containing nonfat dry milk (NDM), $\mathrm{CO}_{2}$-treated milk protein concentrate (TMPC), lactose, and demineralized water

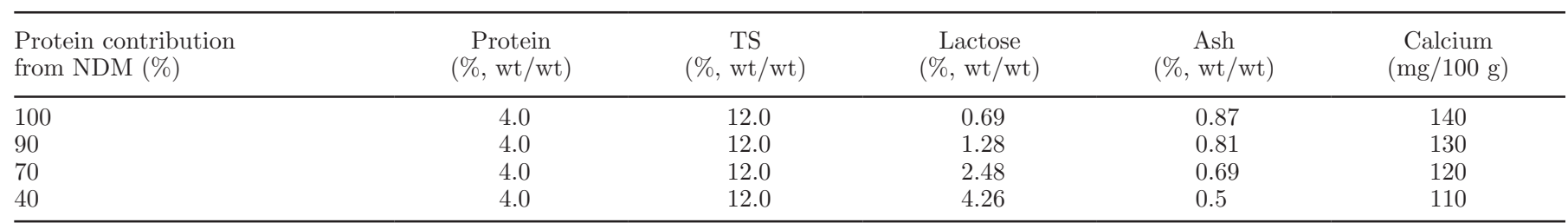

UF or DF step is employed. In the current set of experiments, $\mathrm{CO}_{2}$ treatment before and during the process of UF or DF would have partially removed solubilized minerals into permeate leaving less opportunity for reaggregation of casein micelles in the retentate.

Whey protein levels in the supernatant of unheated milk protein suspensions were not affected by the amount of TMPC80 in the samples (Figure 1, gel A). In contrast, the level of whey protein in the supernatants of heated samples was strongly influenced by the proportion of TMPC80 in the samples (Figure 1, gel B). Levels of whey proteins in the supernatant of heated samples were lower than in unheated samples in every case due to heat-induced denaturation of whey proteins and their association with casein micelles. With increasing amounts of TMPC80, and hence increasing proportions of nonmicellar casein, the level of whey proteins in the supernatant of heated samples increased. Levels of $\alpha_{\mathrm{s}^{-}}$and $\beta-\mathrm{CN}$ in the supernatant were not strongly affected by heat treatment, whereas heating increased the amount of $\kappa$-CN in the supernatant of all samples as a result of heat-induced dissociation of $\kappa-\mathrm{CN}$.

The particle size of unheated suspensions was not influenced by the amount of TMPC 80 in samples, with average particle size representative of casein micelles (Figure 2). For heated samples, an increase in particle size was observed for all samples, but the extent was considerably larger in samples containing lower levels of TMPC80 (Figure 2). The increase in particle size in the samples containing NDM as the sole protein source was in agreement with previous observations (Anema, 2007; Anema et al., 2004; Jeurnink and De Kruif, 1993) and can be attributed to denatured whey proteins associating with the casein micelles. The progressive decrease in particle size of heated dispersions (Figure 2) correlated with increasing proportion of TMPC80, which corresponds to increased soluble phase aggregates (Figure 1). As Anema (2007) outlined, $\beta$-LG preferentially

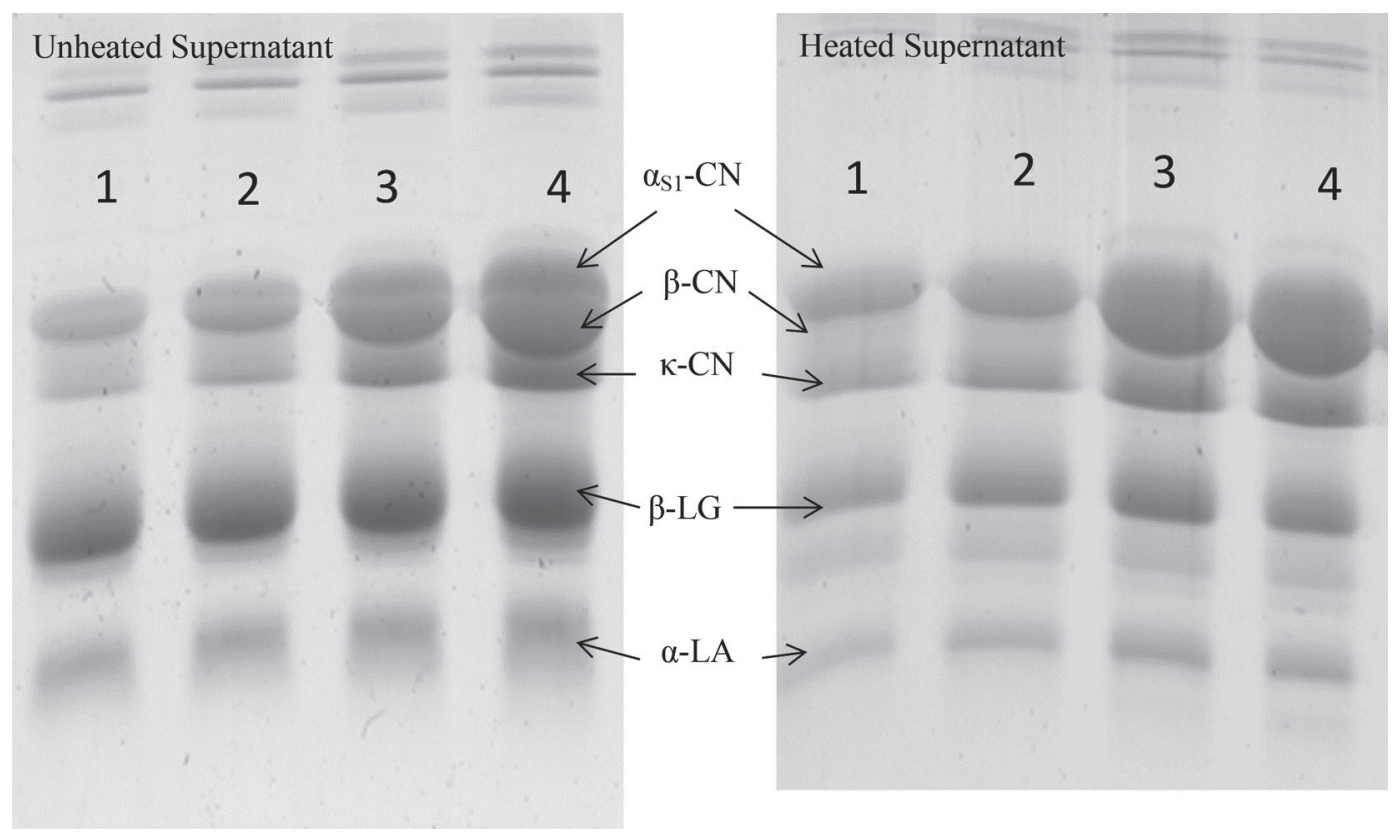

Figure 1. Reduced SDS-PAGE gels of supernatants from unheated and heated $\left(10 \mathrm{~min}\right.$ at $\left.90^{\circ} \mathrm{C}\right)$ dispersions $(4.0 \%$ total protein) having nonfat dry milk (NDM) protein contribution percentage of 100 (lane 1), 90 (lane 2), 70 (lane 3), and 40\% (lane 4), respectively. 


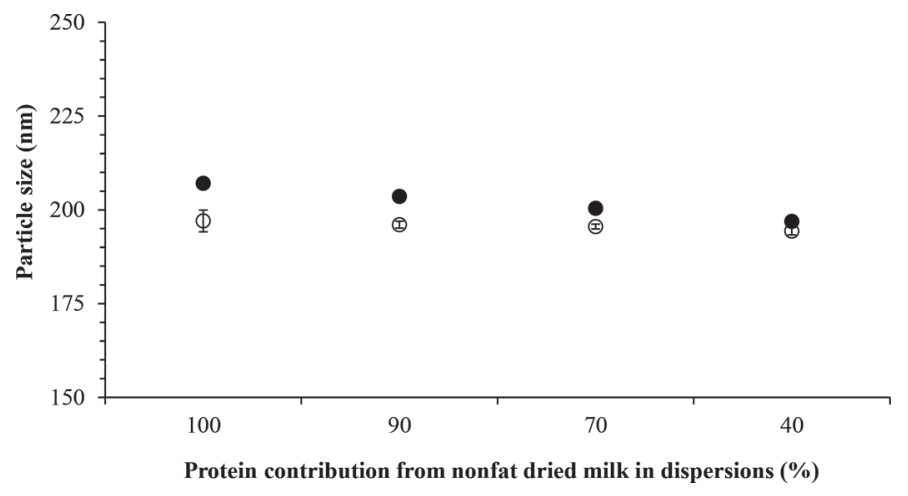

Figure 2. The Z-average particle diameter of unheated $(\bigcirc)$ or heated $\left(\bullet ; 90^{\circ} \mathrm{C}\right.$ for $\left.10 \mathrm{~min}\right)$ suspensions $(4.0 \%$ total protein) containing different protein percentage contribution from nonfat dry milk (NDM). Error bars indicate SE.

interacts with $\kappa$-CN in the serum phase; hence, less whey protein is expected to associate with the micelles, limiting heat-induced increases in particle size.

The acidification curves for heated MPC suspensions are shown in Figure 3. With an increase in protein contribution ratios from TMPC80, we noted a decrease in amounts of $0.5 \mathrm{~N} \mathrm{HCl}$ required to reduce $\mathrm{pH}$ from 6.5 to 3.0. This progressive decrease in buffering capacity can be related to the removal of buffering compounds during manufacture of TMPC80, primarily phosphate and citrate. During traditional MPC80 production, soluble salts are removed by UF and DF, resulting in a lower buffering capacity (Meletharayil et al., 2015, 2016).

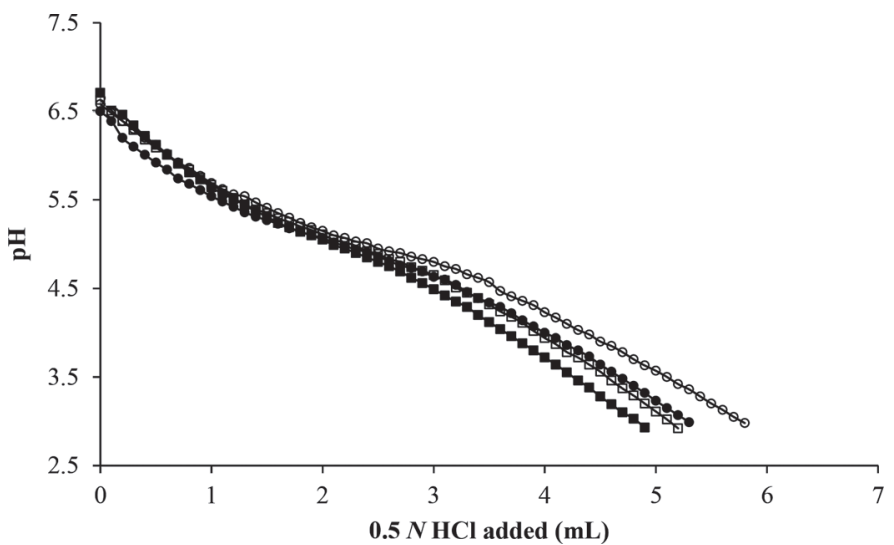

Figure 3. Influence of added $0.5 \mathrm{~N} \mathrm{HCl}$ on the $\mathrm{pH}$ of heated (10 min at $90^{\circ} \mathrm{C}$ ) dispersions $(30 \mathrm{~g})$ containing nonfat dry milk (NDM) and $\mathrm{CO}_{2}$-treated milk protein concentrate (TMPC80). the NDM protein contributions were $100(\bigcirc), 90(\bullet), 70(\square)$, and $40 \%(\square)$.

Furthermore, the application of $\mathrm{CO}_{2}$ during MPC production induced solubilization of CCP (Marella et al., 2015), which was subsequently removed during UF and DF.

\section{Acid Gelation Properties}

The development of elastic modulus $\left(\mathrm{G}^{\prime}\right)$ and loss tangent $(\tan \delta)$ during acid gelation of heated samples is shown in Figures 4 and 5, respectively. Table 2 summarizes several key parameters of the acid gelation process [i.e., $\mathrm{pH}$ at which gelation commenced, $\mathrm{G}^{\prime}$ at

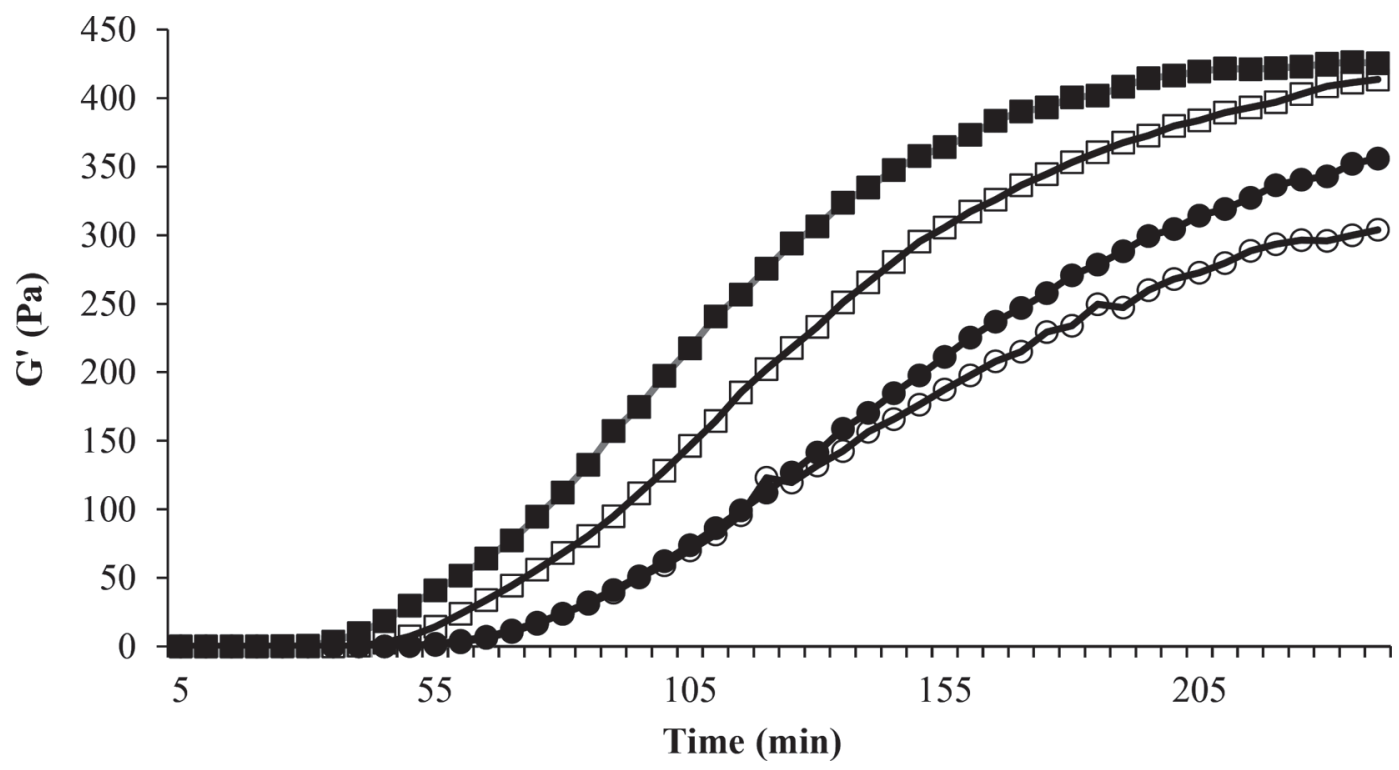

Figure 4. Elastic modulus $\left(\mathrm{G}^{\prime}\right)$ of acid gels as a function of time during glucono- $\delta$-lactone $(\mathrm{GDL})$ acidification at $30^{\circ} \mathrm{C}$ of heated $(10$ min at $90^{\circ} \mathrm{C}$ at $\mathrm{pH}$ 6.5) dispersions containing nonfat dry milk (NDM) and $\mathrm{CO}_{2}$-treated milk protein concentrate (TMPC80). The NDM protein contributions were $100(\bigcirc), 90(\bullet), 70(\square)$, and $40 \%(\mathbf{\square})$. 


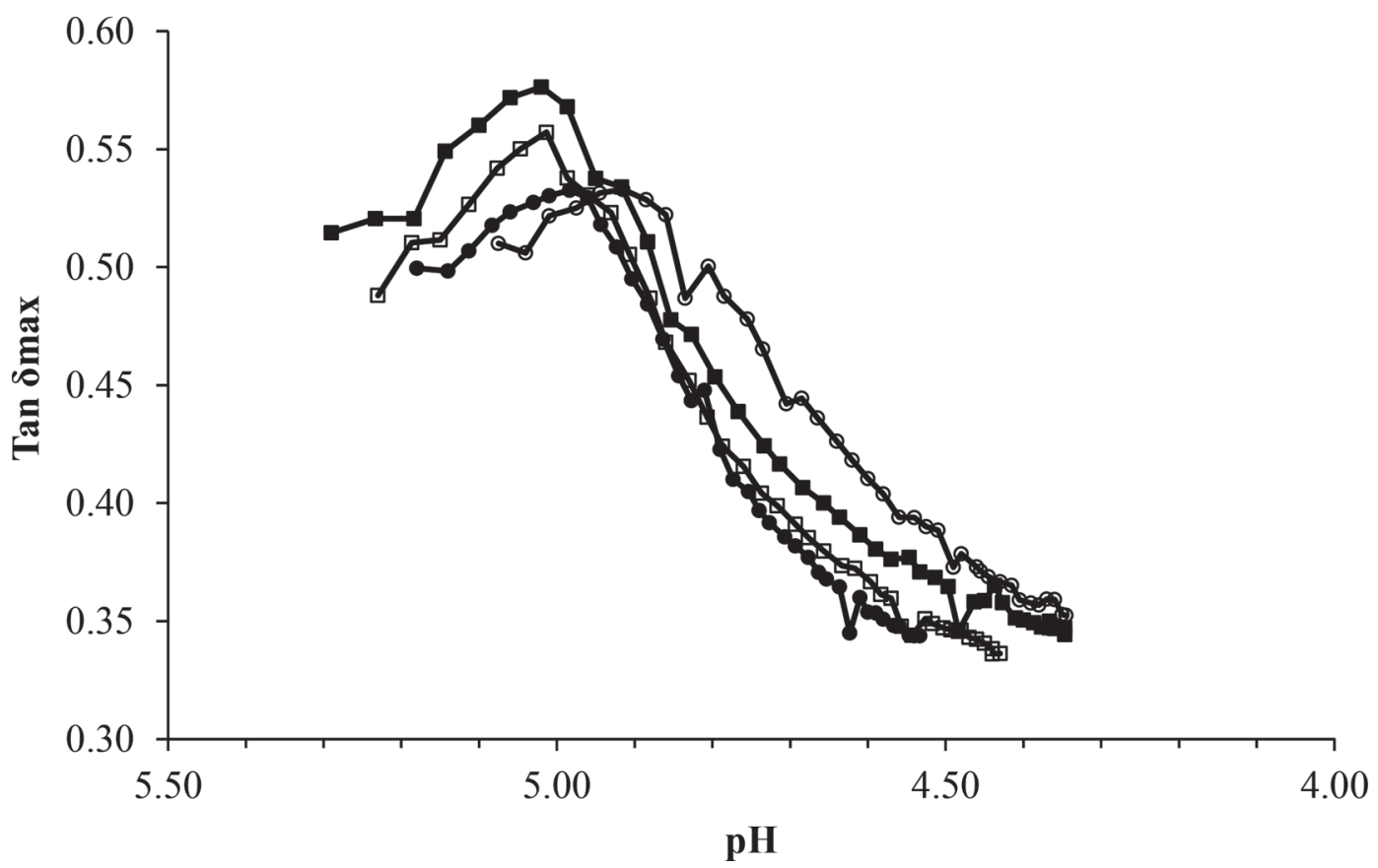

Figure 5. Maximum in loss tangent $\left(\tan \delta_{\max }\right)$ values as a function of $\mathrm{pH}$ during glucono- $\delta$-lactone $(\mathrm{GDL})$ acidification at $30^{\circ} \mathrm{C}$ of heated $(10$ min at $90^{\circ} \mathrm{C}$ at $\mathrm{pH} 6.5$ ) dispersions containing nonfat dry milk (NDM) and $\mathrm{CO}_{2}$-treated milk protein concentrate (TMPC80). The NDM protein contributions were $100(\bigcirc), 90(\bullet), 70(\square)$, and $40 \%($
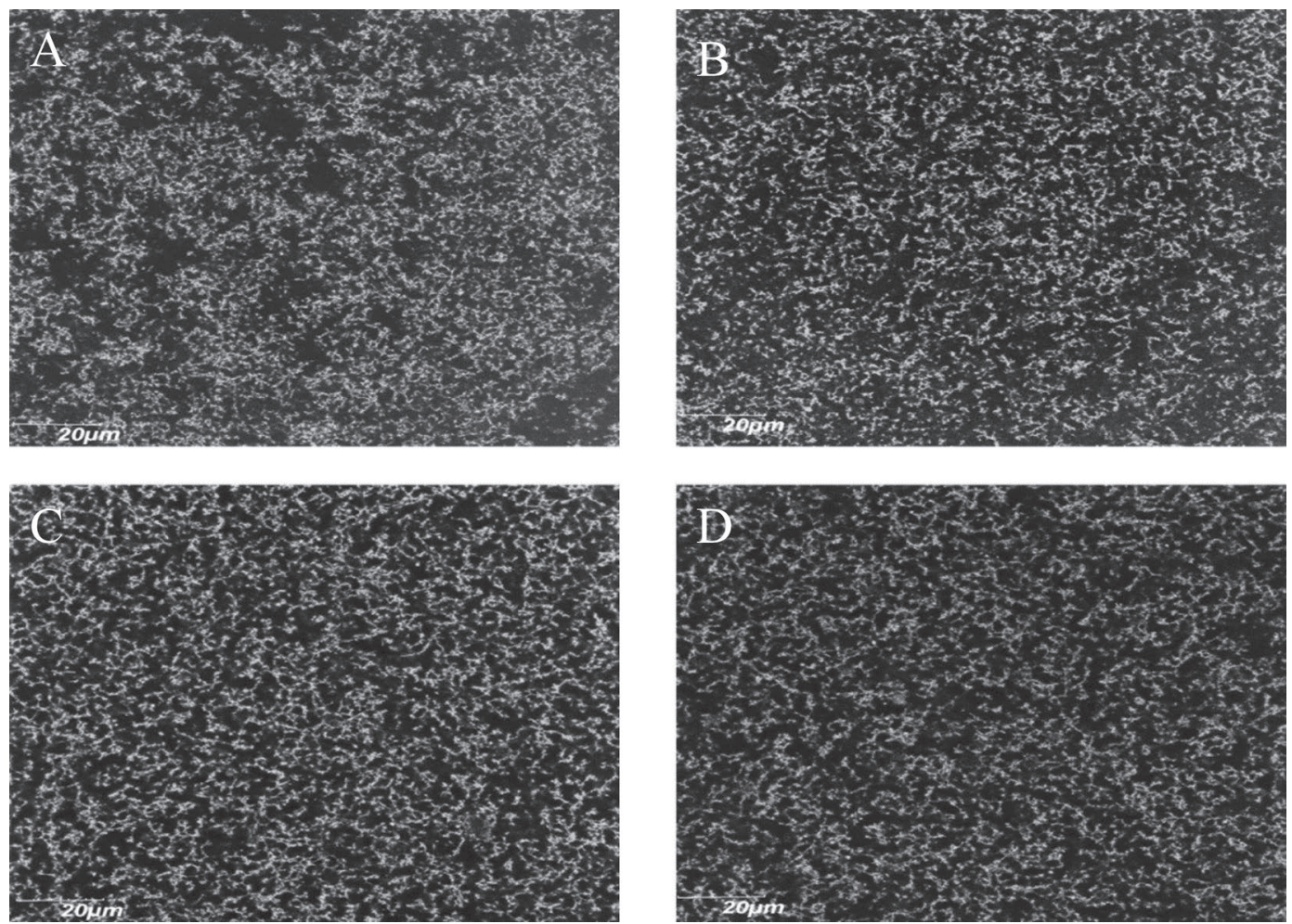

Figure 6. Confocal images of acid gels made by glucono- $\delta$-lactone (GDL) acidification at $30^{\circ} \mathrm{C}$ of heated $\left(10 \mathrm{~min}\right.$ at $90^{\circ} \mathrm{C}$ at $\left.\mathrm{pH} 6.5\right)$ dispersions containing nonfat dry milk (NDM) and $\mathrm{CO}_{2}$-treated milk protein concentrate (TMPC80). The NDM protein contributions were 100 (A), 90 (B), 70 (C), and $40 \%$ (D). 
Table 2. Rheological properties of acid gels from heated dispersions containing nonfat dry milk (NDM), $\mathrm{CO}_{2}{ }^{-}$ treated milk protein concentrate (TMPC), lactose, and demineralized water (values are means of data from at least duplicate analysis)

\begin{tabular}{lcccc}
\hline & \multicolumn{3}{c}{ Protein contribution from NDM (\%) } \\
\cline { 2 - 5 } Parameter & 100 & 90 & 70 & 40 \\
\hline Elastic modulus $(\mathrm{Pa} ; \mathrm{pH} 4.6)$ & $304^{\mathrm{c}}$ & $356^{\mathrm{b}}$ & $414^{\mathrm{a}}$ & $425^{\mathrm{a}}$ \\
pH at gelation & $5.08^{\mathrm{c}}$ & $5.22^{\mathrm{b}}$ & $5.27^{\mathrm{ab}}$ & $5.30^{\mathrm{a}}$ \\
Maximum in loss tangent $\left(\tan \delta_{\max }\right)$ & $0.53^{\mathrm{b}}$ & $0.54^{\mathrm{b}}$ & $0.56^{\mathrm{b}}$ & $0.58^{\mathrm{a}}$ \\
pH at tan $\delta_{\max }$ & $4.98^{\mathrm{c}}$ & $5.03^{\mathrm{b}}$ & $5.05^{\mathrm{b}}$ & $5.10^{\mathrm{a}}$ \\
Water-holding capacity $(\%)$ & $61.7^{\mathrm{c}}$ & $67.1^{\mathrm{ab}}$ & $65.2^{\mathrm{b}}$ & $69.2^{\mathrm{a}}$ \\
Porosity $(\%)$ & $50.5^{\mathrm{a}}$ & $45^{\mathrm{b}}$ & $26^{\mathrm{c}}$ & $27^{\mathrm{c}}$ \\
\hline
\end{tabular}

${ }^{\mathrm{a}-\mathrm{c}}$ Means within the same row not sharing a common superscript are significantly different $(P<0.05)$.

$\mathrm{pH} 4.5$, the maximum value for $\tan \delta$, and $\mathrm{pH}$ at which maximum in loss tangent ( $\left.\tan \boldsymbol{\delta}_{\max }\right)$ occurred]. The $\mathrm{pH}$ at which gelation occurred increased with an increasing proportion of TMPC80 in the samples, as did $\mathrm{pH}$ at which $\tan \delta_{\max }$ occurred (Figure 4 and 5, Table 2). The former can probably be attributed to higher levels of whey protein- $\kappa-\mathrm{CN}$ aggregates in the serum phase of milk, as previously reported for milk heated at different $\mathrm{pH}$ values (Singh and Fox, 1985; Anema and Klostermeyer, 1997). The increase in $\mathrm{pH}$ at which $\tan \delta_{\max }$ occurred was probably due to the lower mineral content of samples with increasing levels of TMPC80 (Table 1). Previous studies have shown that the $\mathrm{pH}$ at which tan $\delta_{\max }$ increases with increasing level of demineralization of casein micelles (Anema, 2009). The $\mathrm{G}^{\prime}$ at $\mathrm{pH} 4.5$ also increased with increasing proportion of TMPC80 in the samples. This effect may be attributable to the higher gelation $\mathrm{pH}$, as plotting $\mathrm{G}^{\prime}$ at $\mathrm{pH} 4.5$ versus the $\mathrm{pH}$ difference between gelation $\mathrm{pH}$ and $\mathrm{pH} 4.5$ yielded a linear correlation $\mathrm{G}^{\prime}$ at $\mathrm{pH} 4.5=523 \times($ gel $\mathrm{pH}-4.5)$, with $\mathrm{R}^{2}$ $=0.97$ (data not shown); that is, $\mathrm{G}^{\prime}$ was proportional to the amount of time gels were below the gelation $\mathrm{pH}$. We noted a steady increase observed in $\tan \delta_{\max }$ values of acid gels containing increasing amounts of protein from TMPC80, which can be attributed to the fact that micellar destabilization due to CCP solubilization occurred at higher $\mathrm{pH}$. No significant difference in final $\tan \delta$ values of the gels after incubation was observed.

\section{Properties of Acid Gels}

Confocal images of acid gels containing varying levels of protein contribution ratios from NDM and TMPC80 are shown in Figure 6, with their corresponding porosity values presented in Table 2 . With an increase in TMPC 80 as the protein source in dispersions, the porosity values of acid gels decreased. Acid gels with 70 and $40 \%$ of protein from NDM yielded gels with the lowest porosity values, indicating a closely knit gel network. These trends correlated with WHC; that is, samples with higher porosity showed lower WHC and vice versa (Table 2 ).

\section{CONCLUSIONS}

The results presented in this study suggest that increasing the amount of nonmicellar casein can improve acid gelation (i.e., in terms of a higher $\mathrm{pH}$ at which gelation commences and a higher $\mathrm{G}^{\prime}$ value at $\mathrm{pH}$ 4.5) as well as decreased porosity and increased WHC. The higher $\mathrm{pH}$ at gelation appears to be the main driver behind our findings, because a strong positive correlation was found between gelation $\mathrm{pH}$ and $\mathrm{G}^{\prime}$ at $\mathrm{pH}$ 4.5. The increased $\mathrm{pH}$ of gelation can be attributed to increased levels of casein-whey protein complexes in the serum phase of samples. Previous studies have highlighted that other means of increasing amounts of casein-whey protein complexes in the serum phase (e.g., by increased $\mathrm{pH}$ at which samples were heated before acidification) and increased $\mathrm{G}^{\prime}$ of gels as well. The use of TMPC80 provides a clear alternative and does not require $\mathrm{pH}$ adjustment before heating, with concomitant long acidification times, and may thus be a viable option to improve acid gel properties.

\section{ACKNOWLEDGMENTS}

The authors acknowledge the financial support of the Midwest Dairy Foods Research Center (Brookings, SD) and the Agricultural Utilization Research Institute (St. Paul, MN).

\section{REFERENCES}

Anema, S. G. 2007. Role of K casein in the association of dentaured whey proteins with casein micelles in heated reconstituted skim milk. J. Agric. Food Chem. 55:3635-3642.

Anema, S. G. 2009. Role of colloidal calcium phosphate in the acid gelation properties of heated skim milk. Food Chem. 114:161-167.

Anema, S. G., and H. Klostermeyer. 1997. Heat-induced, pH-dependent dissociation of casein micelles on heating reconstituted skim 
milk at temperatures below 100 C. J. Agric. Food Chem. 45:1108 1115 .

Anema, S. G., S. Lauber, S. K. Lee, T. Henle, and H. Klostermeyer. 2005. Rheological properties of acid gels prepared from pressureand transglutaminase-treated skim milk. Food Hydrocoll. 19:879887.

Anema, S. G., S. K. Lee, E. K. Lowe, and H. Klostermeyer. 2004. Rheological properties of acid gels prepared from heated $\mathrm{pH}$-adjusted skim milk. J. Agric. Food Chem. 52:337-343.

Aoki, K., J. Shen, and T. Saijo. 2010. Consumer reaction to information on food additives: Evidence from an eating experiment and a field survey. J. Econ. Behav. Organ. 73:433-438.

Faergemand, M., and K. B. Qvist. 1997. Transglutaminase: Effect on rheological properties, microstructure, and permeability of set style acid skim milk gel. Food Hydrocoll. 11:287-292.

Fisberg, M., and R. Machado. 2015. History of yogurt and current patterns of consumption. Nutr. Rev. 73:4-7.

Gastaldi, E., N. Trial, C. Guillaume, E. Bourret, N. Gontard, and J. L. Cuq. 2003. Effect of controlled $\kappa$-casein hydrolysis on rheological properties of acid milk gels. J. Dairy Sci. 86:704-711.

Gevaudan, S., A. Lagaude, B. Tarodo De La Fuente, and J.-L. Cuq. 1996. Effect of treatment of gaseous carbon dioxide on the colloidal phase of skim milk. J. Dairy Sci. 79:1713-1721.

Huppertz, T., P. F. Fox, and A. L. Kelly. 2004. Dissociation of caseins in high pressure-treated bovine milk. Int. Dairy J. 14:675-680.

Imm, J. Y., P. Lian, and C. M. Lee. 2000. Gelation and water binding properties of transglutaminase-treated skim milk powder. J. Food Sci. 65:200-205.
Jeurnink, T. J., and K. G. De Kruif. 1993. Changes in milk on heating: Viscosity measurements. J. Dairy Res. 60:139-150.

Lucey, J. A., and H. Singh. 1997. Formation and physical properties of acid milk gels: a review. Food Res. Int. 30:529-542.

Marella, C., P. Salunke, A. C. Biswas, A. Kommineni, and L. E. Metzger. 2015. Manufacture of modified milk protein concentrate utilizing injection of carbon dioxide. J. Dairy Sci. 98:3577-3589.

Meletharayil, G. H., H. A. Patel, and T. Huppertz. 2015. Rheological properties and microstructure of high protein acid gels prepared from reconstituted milk protein concentrate powders of different protein contents. Int. Dairy J. 47:64-71.

Meletharayil, G. H., H. A. Patel, L. E. Metzger, and T. Huppertz. 2016. Acid gelation of reconstituted milk protein concentrate suspensions: Influence of lactose addition. Int. Dairy J. 61:107-113.

Ozcan-Yilsay, T., W. J. Lee, D. Horne, and J. A. Lucey. 2007. Effect of trisodium citrate on rheological and physical properties and microstructure of yogurt. J. Dairy Sci. 90:1644-1652.

Puvanenthiran, A., R. P. W. Williams, and M. A. Augustin. 2002. Structure and visco-elastic properties of set yoghurt with altered casein to whey protein ratios. Int. Dairy J. 12:383-391.

Singh, H., and P. F. Fox. 1985. Heat stability of milk: pH-dependent dissociation of micellar $\kappa$-casein on heating milk at ultra high temperatures. J. Dairy Res. 52:529-538.

Vasbinder, A. J., and C. G. de Kruif. 2003. Casein whey proteins interactions in heated milk: The influence of $\mathrm{pH}$. Int. Dairy J. 13:669-677. 